\title{
History as Reflected in Capital Markets: The Case of World War II
}

Frey, Bruno S ; Kucher, Marcel

\begin{abstract}
Historical events are reflected in asset prices. We analyze movements in the price of bonds issued by five European governments and traded on the Swiss bourse between 1928 and 1948, with special attention to the war years. Some war events that are generally considered crucial are clearly reflected in government bond prices. This holds, in particular, for the official outbreak of the war and changes in national sovereignty. But other events to which historians attach great importance are $<$ jats:italic $>$ not $</$ jats:italic $>$ reflected in bond prices, most prominently Germany's capitulation in 1945 .
\end{abstract}

DOI: https://doi.org/10.1017/s0022050700025183

Posted at the Zurich Open Repository and Archive, University of Zurich ZORA URL: https://doi.org/10.5167/uzh-154896

Journal Article

Published Version

Originally published at:

Frey, Bruno S; Kucher, Marcel (2000). History as Reflected in Capital Markets: The Case of World War II. Journal of Economic History, 60(02):468-496.

DOI: https://doi.org/10.1017/s0022050700025183 


\section{History as Reflected in Capital Markets: The Case of World War II}

\section{BRUNO S. FREY AND MARCEL KUCHER}

Historical events are reflected in asset prices. We analyze movements in the price of bonds issued by five European governments and traded on the Swiss bourse between 1928 and 1948, with special attention to the war years. Some war events that are generally considered crucial are clearly reflected in government bond prices. This holds, in particular, for the official outbreak of the war and changes in national sovereignty. But other events to which historians attach great importance are not reflected in bond prices, most prominently Germany's capitulation in 1945.

$\mathrm{T}$ his study looks at changes in the value of financial assets as reflections of historical events. More specifically, the historical events considered here bracket World War II, beginning with Hitler's appointment as chancellor on 30 January 1933 and ending with the two Marshall Plan Conferences in September 1947. We analyze changes in the price of sovereign bonds denominated in Swiss francs and traded on the Swiss bourse during this period. While all the belligerents interfered heavily in-or even closedtheir financial exchanges, the Swiss government, for reasons of neutrality, refrained from doing so (except for the two months following the German attack against the West in May and June 1940, when the Swiss bourse did close). Five issuers dominated the Swiss government-bond market: Germany, the main aggressor in World War II; Austria, a country integrated into the Third Reich well before the outbreak of the war; France, Germany's traditional enemy in the West; and Belgium and Switzerland, two neutral countries, the first of which was drawn into the war, while the latter was spared direct involvement. There was only very limited trading in the bonds of other governments.

In this study we address two questions that approach the relationship between historical events and capital markets from opposite angles. First, to what extent can changes in government-bond prices be related to historical events? Do all breaks in the price series correspond to what have been established as crucial events in World War II, or are there breaks which

The Journal of Economic History, Vol. 60, No. 2 (June 2000). (O) The Economic History Association. All rights reserved. ISSN 0022-0507.

Bruno S. Frey is Professor and Marcel Kucher is Research Associate at the Institute of Empirical Economic Research, University of Zürich, Blümlisalpstrasse 10, CH-8006 Zürich, Switzerland. Email: bsfrey@iew.unizh.ch.

We are grateful to Gary S. Becker, Matthias Benz, Knut Borchardt, Robert Chirinko, Werner De Bondt, Reiner Eichenberger, Lars Feld, Lorenz Goette, Timothy Guinnane, Jakob de Haan, Reto Jegen, Gebhard Kirchgaessner, Felix Oberholzer-Gee, Jan Osterloh, Juerg de Spindler, Peter Stolz, Isabelle Vautravers, Jan de Vries, and two anonymous referees for their helpful comments. 
cannot (or cannot easily) be related to these events? Second, to what extent are historical events reflected as changes in the values of government bonds? Do capital values rise or fall, and how large and significant are the changes? Are bonds issued by the various governments affected in the same or in different ways?

We argue that the answers to these questions shed new light on the war. Specifically, some events that are generally thought to be crucial are clearly reflected in the prices of the bonds under study. This holds true, in particular, for the "official" outbreak of the war in September 1939 (which depressed the prices not only of Austrian, Belgian, and French, but also of German government bonds), and for losses and gains of national sovereignty. When Austria lost its independence and became part of Grossdeutschland, for example, the value of its sovereign bonds fell by 46 percent; when it regained its nationhood at the Potsdam Conference, their value rose by 12 percent. Similarly, when Belgium and France were overrun by German forces in the Blitzkrieg of May 1940, their government bonds fell by no less than 35 percent and 31 percent respectively. On the other hand, some events to which historians attach great attention are not reflected in bond prices at all: The most prominent example is Germany's capitulation in 1945, which did not affect German government-bonds prices.

\section{HISTORICAL EVENTS, INTERPRETATION, AND CAPITAL MARKETS}

Many historical events are generally undisputed and their dating poses few problems. In our context, an example would be Hitler's appointment as chancellor, which took place on 30 January 1933 (and not, say, in 1930 or 1936). Similarly, the Wehrmacht's unconditional surrender took place in Reims on 7 May 1945, and was repeated in Berlin on 9 May (and not, say, in March or April). But even these events are not just facts; they are acts of historical simplification. Thus, in the case of the German capitulation, it could be argued that there were still some Wehrmacht units fighting after these dates, so that a more appropriate date for the capitulation would be later. Interpretation is thus a crucial element in historical research, and in interpreting the past great care must be taken not to distort it. In particular, when past decisions are evaluated the knowledge existing at that particular time must be taken into account. This is particularly important when decisions turn out to be wrong. For instance, it is not easy to understand, ex post facto, why Hitler ordered the invasion of the Soviet Union, because according to what we know in hindsight, defeat was almost inevitable. Scholars make an effort to overcome these dangers by careful study of official and private documents, such as diaries, which are likely to be representative of the situation as perceived at a particular moment in time. But it is also a 
well-known fact that extant documents are already the result of a selection process (mainly those documents considered "important" being preserved), and many of them are rewritten afterwards. An example is Hitler's Tischgespräche im Führerhauptquartier, the transcriber of which, it is now known, inadvertently inserted arguments and comments many years after the war. It is possible that these later insertions do not fully reflect Hitler's original statements in $1940 .^{1}$

According to efficient-market theory, capital markets offer three particular advantages over other data sources. ${ }^{2}$ First, provided they are correctly recorded (which is probable since bourses are public or quasi-public), securities prices reflect the situation obtaining at the given point in time. The future is not known, nor can it be incorporated into these data retroactively. What can be registered are the decision makers' subjective expectations about the future, which is a wholly different matter. Our dataset captures the mood existing among investors at a given point in time, for instance expectations regarding the likelihood of Germany winning the war and honoring its foreign debts. Second, investors are likely to evaluate carefully the prevailing situation, as well as any likely future developments, because errors directly affect their pocketbooks. Even a Nazi sympathizer had to weigh the probability of default on, or repudiation of, German government bonds should Germany lose the war. Failure to do so incurred a great risk of capital loss. This too distinguishes capital markets from other data sources, particularly surveys and questionnaires. A final advantage is that financial markets usually exhibit a high predictive power, due to so-called marginal traders. This type of trader carefully assesses the relevant information and acts on a relatively unbiased basis. In the extreme case, one such trader can drive the market price to the underlying equilibrium. ${ }^{3}$

On the other hand, one must also bear in mind the limitations of this method. Most importantly, traders of government bonds are only interested in the likely financial consequences of political events. They seek to evaluate how a given event affects the probability that debt will be serviced and ultimately redeemed. Capital markets, moreover, and especially the government-bond market, do not reflect the general state of economic and political expectations at a particular point in time. Rather, they capture the expectations of a special group of people, not only floor traders but also the much larger group of underlying investors. It would be of considerable interest to know exactly who the ultimate buyers and sellers on the government bond market were during the period in question. But no records exist as to the

\footnotetext{
${ }^{1}$ Umer, Schweiz.

${ }^{2}$ See for example Fama "Efficient Capital Markets."

${ }^{3}$ On the marginal trader and the Hayek hypothesis see Smith, "Markets"; or Forsythe et al., "Anatomy."
} 
identity of these persons; their characteristics can be determined only in general terms (that will be explored later).

Our analysis of break-points does not identify historical facts, but rather the acquisition and assessment of information relevant for bondholders. Investors followed the news not for its own sake, but in order to predict what would happen to the bonds they owned or considered acquiring. Events were evaluated with respect to their impact on the probability of government debt service. Some events of the war years were deemed important and thus influenced bond prices, while others did not affect the perceived probability of debt service, and therefore were not reflected in bond prices.

In Switzerland during the war, information was very quickly and reliably disseminated both in the press and on radio. ${ }^{4}$ This raises the question of whether financial markets might have registered historical facts in advance. In such a case, a break would be visible before the event, or completely absent, depending on the speed of adjustment. Either way, no break would be visible at the date of the event itself. There exists suggestive evidence, however, that financial markets tend to overreact to the arrival of news. ${ }^{5}$ The overreaction hypothesis implies that even if many investors have predicted an event well in advance, and financial markets have adjusted accordingly, a break in the price series can still be identified.

\section{THE GOVERNMENT BOND MARKET}

During World War II, as so often before, belligerent governments directly or indirectly intervened in markets under their control, including financial markets. In Germany in particular, many foreign-exchange restrictions were either introduced or tightened soon after the Nazi takeover in $1933 .^{6}$ The only market where bonds of the governments under consideration were freely traded was the Swiss bourse. For reasons of neutrality, the Swiss government controlled neither transactions nor prices, and there were no restrictions on foreign investors. Trading was halted only during May/June 1940 , when it was unclear whether German forces would outflank the Maginot Line to the north (through Belgium and the Netherlands) or to the south (through Switzerland).

Many governments issued bonds in Switzerland during the interwar years. Here we are only considering obligations of national governments. The foreign governments that borrowed most in the Swiss capital market were France and Germany, followed by Belgium and Austria. The value at emis-

\footnotetext{
${ }^{4}$ See for example Salis, Chronik, or Moos, Grosse Weltgeschehen.

'See for example De Bondt and Thaler, "Does the Stock Market?"

${ }^{6}$ Many of the German capital controls had been introduced during the banking crises in September 1931 and were only tightened by the Nazi government. The Nazis did, however, add some new restrictions, such as those on transfers of interest payments.
} 
sion of Germany's sovereign debt was roughly SFr 3 billion, France's SFr 3.6 billion, Belgium and Austria's SFr 1 billion and SFr 590 million, respectively (all 1999 values). ${ }^{7}$ Our analysis considers a weighted index of the values of all government bonds issued in Switzerland after 1922 for each of these four countries. It is important to note that all of the aforementioned bonds were issued and traded in Swiss francs. Bondholders were therefore protected against debased repayments. Exchange-rate fluctuations could theoretically alter the probability of debt service by changing its real cost. But since exchange rates of most currencies were fixed against the Swiss franc during World War II (the sole exception being the U.S. dollar), the latter effect was probably of slight importance.

Due to the large number of Swiss government bonds traded on this market, we restrict ourselves to the twelve largest issues. A value index has been constructed by comparing the average rate of return on these bonds to the average monthly rate of return on the twelve largest Swiss government bonds over the period from 1906 to $1925 .^{8}$

No information is available on who traded at the Swiss stock exchange during World War II. But as we have mentioned before, even if we knew their identity, it would remain unclear whose money they were investing. Given the high degree of openness of the Swiss financial market, it seems likely that investors from all over Europe used this "safe haven." There is, however, some limited information available concerning the volume of trading in government bonds on the Swiss bourse. The Swiss National Bank did not keep records on turnover in stocks or bonds; but turnover was taxed and the returns have been used to estimate the extent of trading. According to Hubert Schwab, trade in foreign government bonds fell from about $\operatorname{SFr}_{1999}$ 18 billion in 1937 to about 3.5 billion in 1943, rebounding thereafter to about 7 billion in $1946 .{ }^{9}$ German and French government bonds each accounted for roughly 30 percent of the annual turnover, whereas the respective shares of Belgium and Austria stood at 7 and 6 percent. In 1937 trading in Swiss government bonds amounted to about half that of all foreign bonds. During the war, investing in government bonds of the belligerents grew

\footnotetext{
${ }^{7}$ All amounts indicated in this paragraph are in 1999 Swiss francs. For the conversion of war-era prices into 1999 equivalents we only took inflation into account. Since the Swiss CPI is nowadays about 6.9 times higher than during World War II, values at emission were multiplied by 6.9 in order to get 1999 Swiss francs. So, for example, the actual value for the 31 German government bonds at time of emission was only roughly SFr 460 million. However, some researchers (such as Jost, Politik und Wirtschafi) point out that not only inflation, but also the development over time of national income, should be taken into account when converting prices. This, of course, would yield considerably higher values in 1999 Swiss francs.

' For December 1939, for example, the average return of the twelve bonds was 4.25 percent. Comparing this to the 4.42 percent average return for the period from 1906 to 1925 yields an index of 104.00 ((4.42/4.25)・ 100).

${ }^{9}$ Schwab, Schweizerische Effektenmarkt.
} 
increasingly risky, so investors shifted money into Swiss government bonds. The best estimates available indicate an annual turnover of approximately SFr $_{1999} 9$ billion in 1937, 4.5 billion in 1940, and 13 billion in 1946.

World War II "officially" started with the German invasion of Poland in September 1939, and ended in the West with the unconditional surrender of the German forces in May 1945. In many respects, however, the war started earlier, perhaps with the occupation of the Rhineland by Germany in March 1936, or the invasion of Czechoslovakia in March 1939. It could even be argued that the war was a direct consequence of the Nazi takeover in January 1933. To answer the question whether it makes sense to look at this period as a form of war preceding the official declarations, we include monthly data extending from December 1933 (December 1928 for Swiss bonds) to December $1948 .{ }^{10}$ All data have been collected from monthly reports of the Swiss National Bank. ${ }^{11}$

\section{ECONOMETRIC METHODS}

Our basic method is to search for structural breaks in these series of government-bond prices. In contrast to an event study, the starting point is not a list of dates, with the data then revealing which of them "matter." Rather, the method used here allows the data to speak for itself, without $a$ priori specification of the dates.

The basic idea behind the procedure used is to estimate random walks within small time windows and then to test for differences in mean bond prices between these windows. This will provide information on threats common to all the countries considered. While this method might be useful to answer a variety of questions regarding events that affected all bonds, it also means that nothing can be said about country-specific threats. Therefore, in a second step, we test for country-specific threats by estimating conditional random walks and then testing for differences in the mean bond prices for each country. The term "conditional" must be stressed here, since the second procedure corrects for factors influencing all government bonds

\footnotetext{
${ }^{10}$ Unfortunately, higher-frequency data are not available. While weekly or daily observations are econometrically unnecessary, monthly data might mislead: Suppose that Event A raised bond prices early in the month, while Event $B$ lowered them later on. The data will report this as a wash and we will miss two potentially important events. Or the data might say that something happened in, say, November; but if several things happened in November, then one might find oneself at a loss to say which particular event it was that moved the prices. However, while we cannot exclude the possibility that we missed some dates in our study due to the usage of monthly data, we have never encountered two important events in the month before a break-point. So while daily data might enable us to identify events with greater precision, we do not think that they would lead us to new insights.

"Data for the Swiss series can be found in the Swiss National Bank's Monatsberichte, tables 13 (1928 to 1930), 12 (1931 to 1938 and 1942 to 1944), 9 (1939 to 1941 and 1947 to 1949), and 10 (1945 to 1946); indices for foreign government bonds are taken from tables 14 (1934 to 1938 and 1941 to 1946), 18 (1939), 17 (1940) and 12 (1947 to 1949).
} 
in a similar way. We will therefore not find breaks in, say, the German government bond index as a result of changing inflation or real interest rates. This holds also for mean differences: the second procedure only tests for significant structural mean breaks in bond prices conditional to the price movements of all government bonds traded in Switzerland. For example, an event that led to a 10-percent increase in Swiss government-bond prices and to a 5-percent increase of the prices of all government bonds will increase the conditional mean of the Swiss bond prices by 5 percent only. It also means that an event that has the same effect on the bond prices of all countries will not be recognized. ${ }^{12}$

In order to find all possible dates for structural breaks, we apply a fourstep procedure based on the work of Anindya Banerjee, Robin Lumsdaine, James Stock, and Pierre Perron. ${ }^{13}$ Similar methods have previously been applied effectively by Russel Sobel, Kristen Willard, Timothy Guinnane, and Harvey Rosen in order to identify breaks in exchange-rate series ${ }^{14}$ For a full account of the technical details, see the Appendix.

\section{FROM STRUCTURAL BREAKS TO HISTORICAL FACTS}

\section{Common Threats, 1933-1948}

As can be seen in Figure 1, there is a strong downturn in the index of all government bonds traded in Switzerland from late 1933 up to the outbreak of World War II. During the war, the index remained relatively stable at around 40 percent of par. One interesting feature is the peak in mid-1944, just about when Allied forces invaded Normandy.

The prewar fall in bond prices mentioned previously is particularly interesting since all five countries were maintaining their interest payments. ${ }^{15}$ In addition, the Swiss government decided on a currency devaluation of approximately 30 percent, as a consequence of which the bank could be expected to loosen the monetary policy. ${ }^{16}$ Since both these factors should have raised bond prices rather than lowered them, it seems likely that the steady

${ }^{12}$ But it will of course show up in the first (unconditional) estimation procedure.

${ }^{13}$ Banerjee, Lumsdaine, and Stock, "Recursive and Sequential Tests"; and Perron, "Great Crash."

${ }^{14}$ Sobel, "Exchange Rate"; and Willard, Guinnane, and Rosen, "Turning Points."

${ }^{15}$ Most of the countries stopped interest payments after the German invasion. For the countries under consideration, this was the case for Belgium as well as for the remaining parts of France, which ceased interest payments in the summer of 1940 and November 1942, respectively. Germany continued interest payments somewhat longer, until June 1943. It is interesting to note that none of the countries formally repudiated its outstanding debt, and all of them resumed interest payments after the war (for more details, see the section titled "Postwar Fate of Bond Prices").

${ }^{16}$ On 26 September 1936 the government repealed the law requiring the Swiss National Bank to back the franc with gold. Nonetheless the bank was still restricted in its monetary policy by a government requirement that it maintain an exchange ratio of roughly $205 \mathrm{mg}$. gold per franc. This decision was taken above the Bank's objections. See Crettol and Halbeisen, Währungspolitische Hintergrïnde, p. 14. 


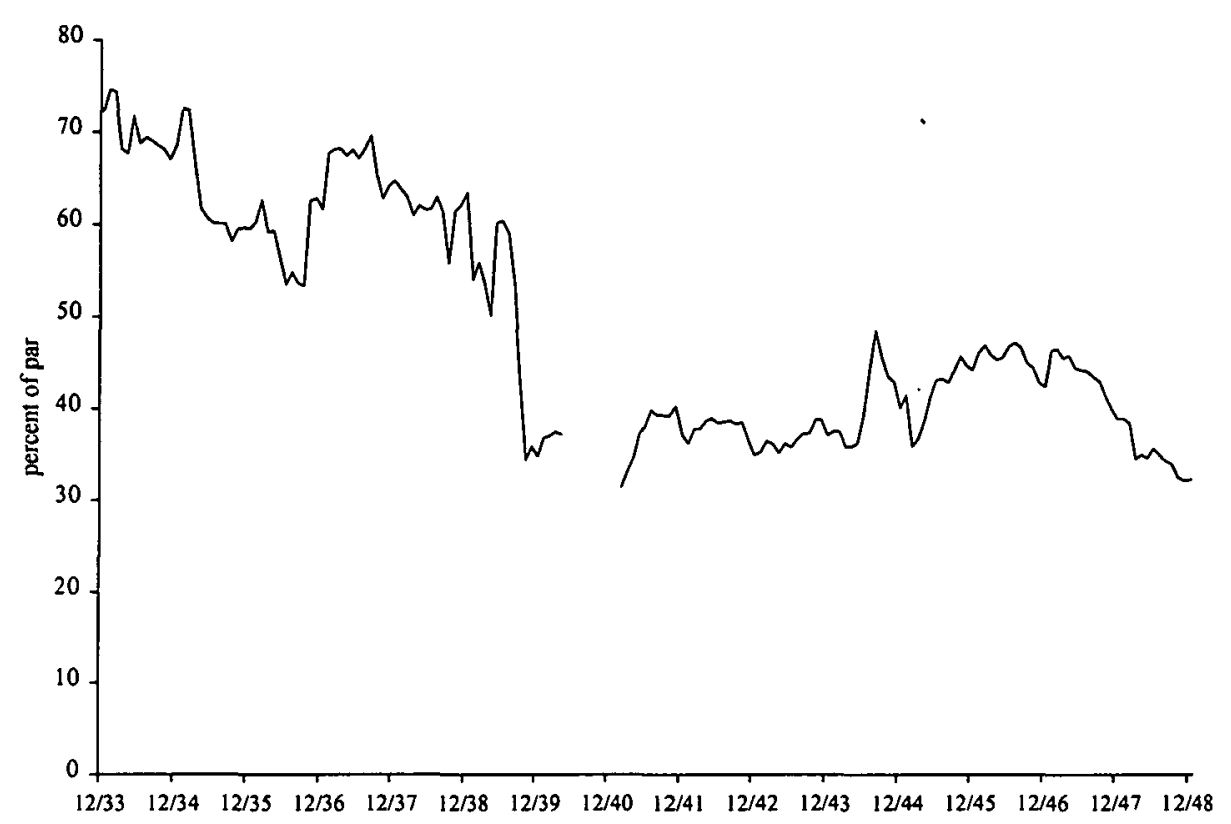

FIGURE 1

INDEX OF ALL GOVERNMENT BONDS TRADED IN SWITZERLAND, 1933-1948

Source: Swiss National Bank, Monatsberichte, 1933-1948.

decline had something to do with the ongoing war preparations. But it remains unclear, prima facie, which events traders deemed important. In order to judge among the alternatives, the method just described may be fruitfully applied. Since in this section we are interested in events that affected all government bonds, we shall seek to isolate break-points in the index of all government bonds by estimating an unconditional random walk.

The four-step procedure identifies nine statistically significant breaks in the time series of all government bonds; these are displayed in Table 1. Each event has the "expected" sign. With the exception of the Swiss devaluation, and to some extent the Marshall Plan Conferences, all of them are related with either causing, prolonging, or shortening the war. The two events indicating an earlier end to the war-the Normandy invasion and, of course, the German capitulation itself-had a positive impact on bond prices. On the other hand, all events indicating that there would be war, that the war would last longer, or that it would involve more countries than previously believed, had a negative impact on the index. Most prominently, the actual outbreak of war reduced bond values by more than one-quarter.

Most of the events identified will be described in detail in the following sections. In this section we will comment only on two events that could not be identified in any of the country-specific estimations. The first is the deval- 
TABLE 1

STRUCTURAL BREAK-POINTS AND CORRESPONDING HISTORICAL EVENTS: ALL GOVERNMENT BONDS TRADED IN SWITZERLAND

\begin{tabular}{lcl}
\hline \hline $\begin{array}{l}\text { Date } \\
\text { (yyyy.mm) }\end{array}$ & $\begin{array}{c}\text { Change in Overall Bond Index* } \\
\text { (percentage) }\end{array}$ & \multicolumn{1}{c}{ Major Events } \\
\hline 1935.03 & $-5.6^{* * *}$ & General Draft in Germany \\
1936.10 & $+2.3^{* * *}$ & Devaluation of the Swiss Franc \\
1939.02 & $-7.7^{* * *}$ & German Invasion of Czechoslovakia \\
1939.09 & $-26.4^{* * *}$ & German Invasion of Poland \\
1941.12 & $-1.7^{* *}$ & Japanese Attack on Pearl Harbor \\
1942.11 & $-1.9^{* *}$ & Russian Counteroffensive at Stalingrad \\
1944.06 & $+5.4^{* * *}$ & Allied Invasion of Normandy \\
1945.04 & $+4.3^{* * *}$ & German Capitulation(s) \\
1947.07 & $-5.2^{* * *}$ & Marshall Plan Conferences \\
\hline
\end{tabular}

- Percentage change in absolute mean.

** = Significant at the 5 percent level.

$* * *=$ Significant at the 1 percent level.

Sources: See the text.

uation of the Swiss franc on 27 September 1936, which had the expected positive impact on bond prices. This "event" cannot be identified in any of the country-specific estimations, probably because it had approximately the same effect on all bonds, and therefore disappears in the conditional randomwalk analyses.

The second such event is the Marshall Plan Conference of July 1947. The idea that a conference deciding on a program to rebuild Europe should have had a negative impact on government bonds seems quite paradoxical, but it was also seen to mark the beginning of the Cold War. The first conference of the Three Powers, in Paris from 27 June to 2 July, was planned to conceptualize the proposals made by U.S. Secretary of State Marshall in June 1947. It soon turned out that the differences between the United States and Britain on the one side, and the Soviet Union on the other, could not be resolved, and the conference ended without the intended results. This failure had important consequences: the common European program, which Marshall had in mind when making his proposals, had turned into a Western European program with several anti-Soviet elements. ${ }^{17}$ The confrontation culminated as first Poland and later all countries under Soviet occupation withdrew their promises to participate in the follow-up conference. ${ }^{18}$ The negative break in the index of all government bond prices suggests that even in 1947 the importance of this withdrawal, which nowadays is widely regarded as the beginning of the Cold War, was understood by the capital markets.

${ }^{17}$ Hardach, Marshall-Plan, pp. 48ff.

${ }^{18}$ Parrish and Narinsky, New Evidence. 
Figure 2 shows the monthly price index of the 31 German government bond issues traded on the Swiss bourse. Visual analysis reveals a secular decline. The steep drop between 1933 and 1935 indicates that bondholders feared that the Nazis would seek to renegotiate their foreign debts, or simply default. This fear was strongly nurtured by official pronouncements advocating extreme autarchy; heavy-handed interventions in the capital markets further depressed bond values. ${ }^{19}$ A moratorium on Versailles reparations payments was declared in mid-1933, at the same time that the government redeemed many foreign bonds in an effort to become as autarchic as possible.

The partial recovery in 1937 and 1938 may be attributed to the (shortterm) success of the expansionary fiscal policy that accompanied rearmament: national income picked up, and unemployment fell sharply. The ratio of foreign to total government debt fell from 18.7 to 5.4 percent. ${ }^{20}$ The Nazis thereby regained some financial respectability with foreign investors. While the German government amassed a huge internal debt to finance armaments and other government expenditures, the probability of foreign-debt service was considered to have improved.

But Hitler's aggressive foreign policy and increasing isolation led to another drastic fall in German bond prices from mid-1938 to the outbreak of war in 1939. Bond traders feared that the impending war would reduce Germany's willingness and ability to service its foreign debt. There was again a rise in the value of German government bonds after the successful Blitzkrieg in the spring of 1940, but it did not last long: from the second half of 1941 there was a permanent fall in German bond values, suggesting that investors expected early on that the Nazis would lose the war, that the debt would no longer be serviced, and that the capital invested would be lost.

Econometric analysis identifies six break-points for Germany. Table 2 gives a survey of the resulting break-points and the corresponding percentage changes in the conditional mean price index. German government bonds experienced a large and statistically significant surge beginning in the summer and autumn of 1936. In July/August of that year, the conditional average index rose by more than 7 percent relative to the conditional mean (that is, to the index of all other government bonds traded on the Swiss market). This might be attributed to the Olympic Games in Berlin, which took place in August and which made the Nazi regime look peaceable to many observ-

\footnotetext{
${ }^{19} \mathrm{German}$ economic policy in the prewar and war period is discussed in Boelcke, Kosten; Kollner, Militar und Finanzen; Milward, War, Economy and Society, Federau, Zweite Weltkrieg, Fischer, Wirtschaftspolitik, and Erbe, Nationalsozialistische Wirtschaftspolitik.

${ }^{20}$ Erbe, Nationalsozialistische Wirtschaftspolitik, p. 51.
} 


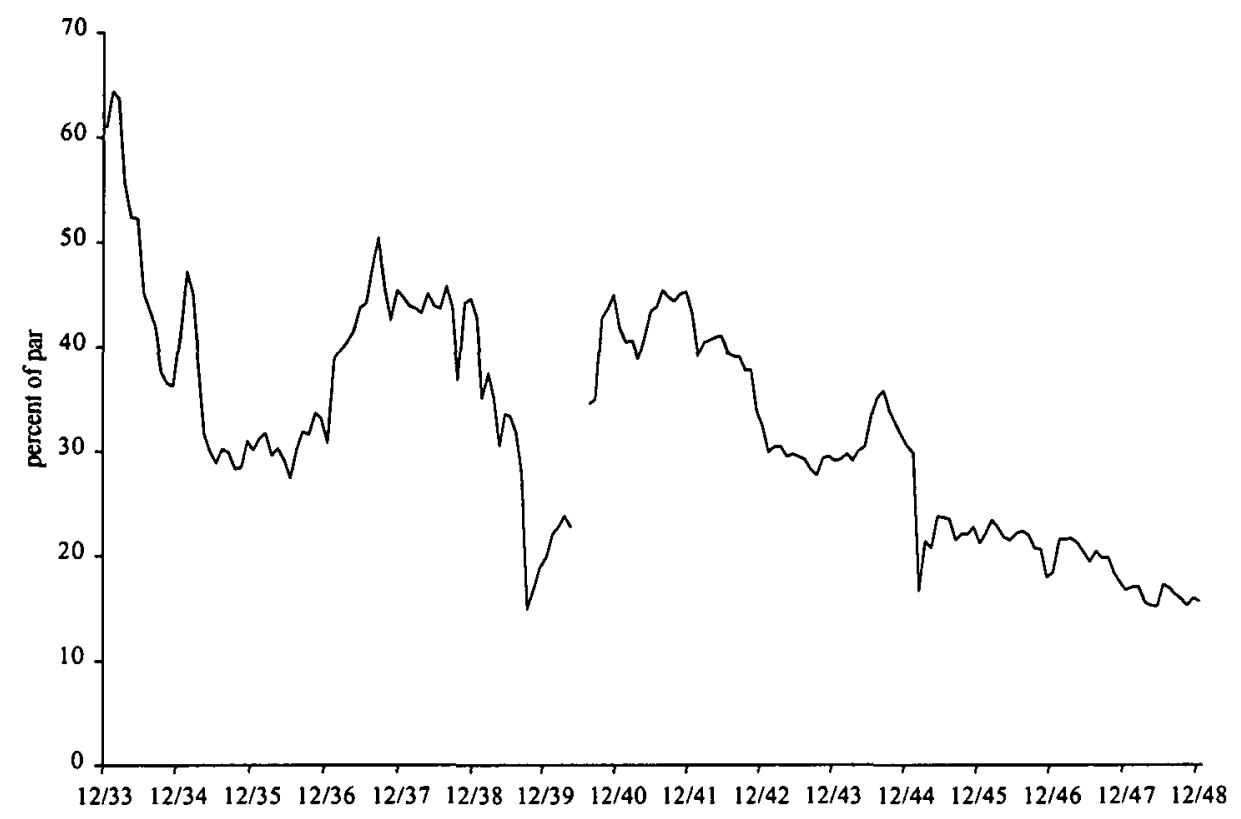

FIGURE 2

INDEX OF 31 GERMAN GOVERNMENT BOND ISSUES TRADED IN SWITZERLAND, 1933-1948

Source: Swiss National Bank, Monatsberichte, 1933-1948.

ers. ${ }^{21}$ The market remained bullish through January 1937, at which point the boom was particularly marked.

In March 1939 Germany invaded those parts of Czechoslovakia not already ceded at the Munich Conference in September 1938. According to many historians, this heralded the beginning of World War II. ${ }^{22}$ The government bond markets support this interpretation of history. The value of German government bonds fell by no less than 17 percent compared to the average market values, indicating that traders had lost even more confidence in the German government's capacity to service its debts. The invasion of Czechoslovakia was the first time Hitler annexed non-"German" territory, which was taken as an indication that he would not stop there, and that a major war was likely. However, some uncertainty remained; some actors on capital markets obviously thought that this conquest had satisfied Hitler's demands. Accordingly, the value of German government bonds dropped only half as much as they would at the "official" outbreak.

\footnotetext{
${ }^{21}$ For example, the French delegation used the fascist salute upon entering the stadium at the Olympic opening ceremony.

${ }^{22}$ See for example Weinberg, World at Arms.
} 
TABLE 2

STRUCTURAL BREAK-POINTS AND CORRESPONDING HISTORICAL EVENTS:

GERMANY

\begin{tabular}{lcl}
\hline \hline $\begin{array}{l}\text { Date } \\
\text { (yyyy.mm) }\end{array}$ & $\begin{array}{c}\text { Change in German Bond Index* } \\
\text { (percentages) }\end{array}$ & \multicolumn{1}{c}{ Major Events } \\
\hline 1936.07 & $+8^{* *}$ & Olympic Games in Berlin (30 July-16 August) \\
1939.03 & $-17^{* *}$ & Invasion of Czechoslovakia (15-16 March) \\
1939.09 & $-39^{* * *}$ & Invasion of Poland (1 September) \\
1941.12 & $-5^{* *}$ & Japanese Attack on Pearl Harbor (7 December) \\
1942.11 & $-7^{* * *}$ & Russian Counteroffensive at Stalingrad (November) \\
1945.02 & $-34^{* * *}$ & Yalta Conference (4 -11 February) \\
\hline
\end{tabular}

- Percentage change in the conditional mean (that is, the parameter $\gamma_{s}$ from equation A2).

** = Significant at the 5 percent level.

*** $=$ Significant at the 1 percent level.

Sources: See the text.

World war became a reality after 1 September 1939, when German troops invaded Poland. Since the end of 1938 capital markets had been interpreting Nazi actions in a strongly negative way. The actual start of the war sent the value of German government bonds plummeting 39 percent. Obviously, traders were extremely pessimistic about the prospects of a German victory.

As already noted, the Swiss bourse was closed in May/June 1940, so the immediate effect of the German Blitzkrieg victories are not reflected in our data. But Figure 2 clearly shows that the average price of German government bonds rebounded to prewar levels. It is worth noting, however, that it did not surpass them. This may be interpreted to indicate that after the Blitzkrieg peace was considered a likely prospect, with "normal" prewar conditions expected to resume.

The fourth structural break is identified in November/December 1941, but the decline of average bond prices is rather small (around 5 percent). It reflects another major war event, namely the Japanese attack on Pearl Harbor ( 7 December) and the consequent war declarations of the United States (and the United Kingdom) on Japan, and of Germany (and Italy) on the United States (8 and 11 December, respectively).

Yet another significant drop in German bond values (about 7 percent) occurred in November 1942. In that month the Soviet army launched a massive counteroffensive against the German invaders. More than 300,000 German troops were encircled at Stalingrad. Traders on the Swiss bourse evidently considered the counteroffensive as even more detrimental to Germany's ability to service its debt than was the capitulation by Field Marshal Friedrich Paulus three months later (2 February 1943).

The last break-point indicated by the German data occurred towards the end of the war, in February 1945. At the Yalta Conference the Allied great powers decided that only a complete capitulation of all German forces on all 


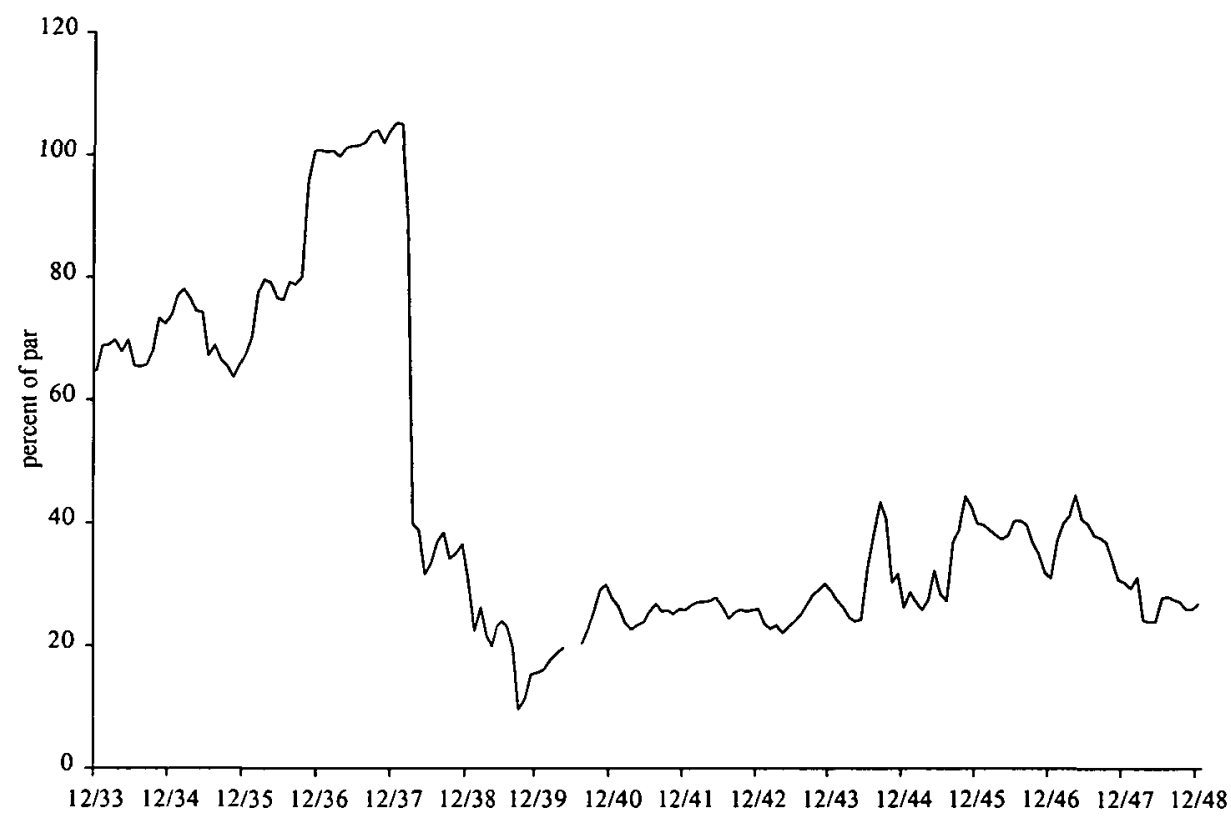

FIGURE 3

INDEX OF 9 AUSTRIAN GOVERNMENT BOND ISSUES TRADED IN SWITZERLAND, 1933-1948

Source: Swiss National Bank, Monatsberichte, 1933-1948.

fronts would be accepted, and that Germany would be divided into three military occupation zones. This was interpreted to be a decisive blow to the Nazis-more so even than the formal capitulation of the German military in May 1945 - and resulted in a fall of German bond prices by 34 percent.

Austria, 1933-1948

Figure 3 tracks the monthly price index of the nine Austrian government bond issues traded in Switzerland. In contrast to Germany, it shows a marked increase between 1933 and 1937. There was a huge drop with the Anschluss of March 1938, and it remained quite depressed thereafter. This drastic fall may be due not only to political factors, but also to the fact that with annexation, they became subject to the severe German controls on capital and foreign exchange. It is worth noting, however, that the Austrian index remained much below its German counterpart until mid-1944, even though Germany had formally assumed all Austrian foreign debts.

Econometric analysis of the Austrian government bond index identifies three statistically significant break-points (see Table 3 ). The index fell by no 
TABLE 3

STRUCTURAL BREAK POINTS AND CORRESPONDING HISTORICAL EVENTS: AUSTRIA

\begin{tabular}{lcl}
\hline $\begin{array}{l}\text { Date } \\
\text { (yyyy.mm) }\end{array}$ & $\begin{array}{c}\text { Change in Austrian Bond Index } \\
\text { (percentages) }\end{array}$ & \multicolumn{1}{c}{ Major Events } \\
\hline 1938.03 & $-46^{* * *}$ & German Annexation of Austria \\
1939.09 & $-46^{* * *}$ & German Invasion of Poland \\
1945.08 & $+12^{* *}$ & Potsdam Conference
\end{tabular}

Percentage change in the conditional mean (that is, the parameter $\gamma_{s}$ from equation A2).

** = Significant at the 5 percent level.

$* * *$ = Significant at the 1 percent level.

Sources: See the text.

less than 46 percent upon the Anschluss in March 1938. A significant drop is visible as of the beginning of the year, when the Nazi government prepared that event. It is noteworthy that traders on the Swiss bourse did not consider the seemingly enthusiastic Austrian support for the Anschluss to be relevant to their interests. The same holds for its near-unanimous ratification in a plebiscite undertaken on 10 April of the same year. ${ }^{23}$

As with German debt, the outbreak of war deeply depressed Austrian government bond values (by 46 percent in September 1939). Oddly, the German capitulation of May 1945 is not reflected in these data. One reason might be that Austria's political future, and thereby the servicing of its debt, was taken to be uncertain; traders were unable to predict clearly how defeat would affect that part of the Reich which had, after all, been annexed by the Germans. This uncertainty was mitigated in July/August of the same year when the Potsdam Conference settled on Austrian independence, a decision reflected in a 12-percent increase in average bond prices.

\section{France, 1933-1948}

The raw data for French government bonds (Figure 4) show a fairly stable value up to mid-1938, followed by huge drops coinciding with the "official" outbreak of the war, the invasion by German forces, and the French capitulation (22 June 1940). After trading resumed at the Swiss bourse, French bonds experienced a secular increase in value up to the end of 1945. It is interesting to note that the value of French government bonds remained above 20 percent of par, even though France suspended interest payments in November 1942 and did not resume debt service until after the period considered. The fact that French government-bond prices did not drop to zero implies a surprising degree of confidence that France would reemerge as an independent nation and resume debt service.

${ }^{23}$ Approximately 4,453,000 of the 4,484,000 electors voted "yes," only 11,924 voted "no," and 5,776 spoiled their ballots. See Henschy, Freedom. 


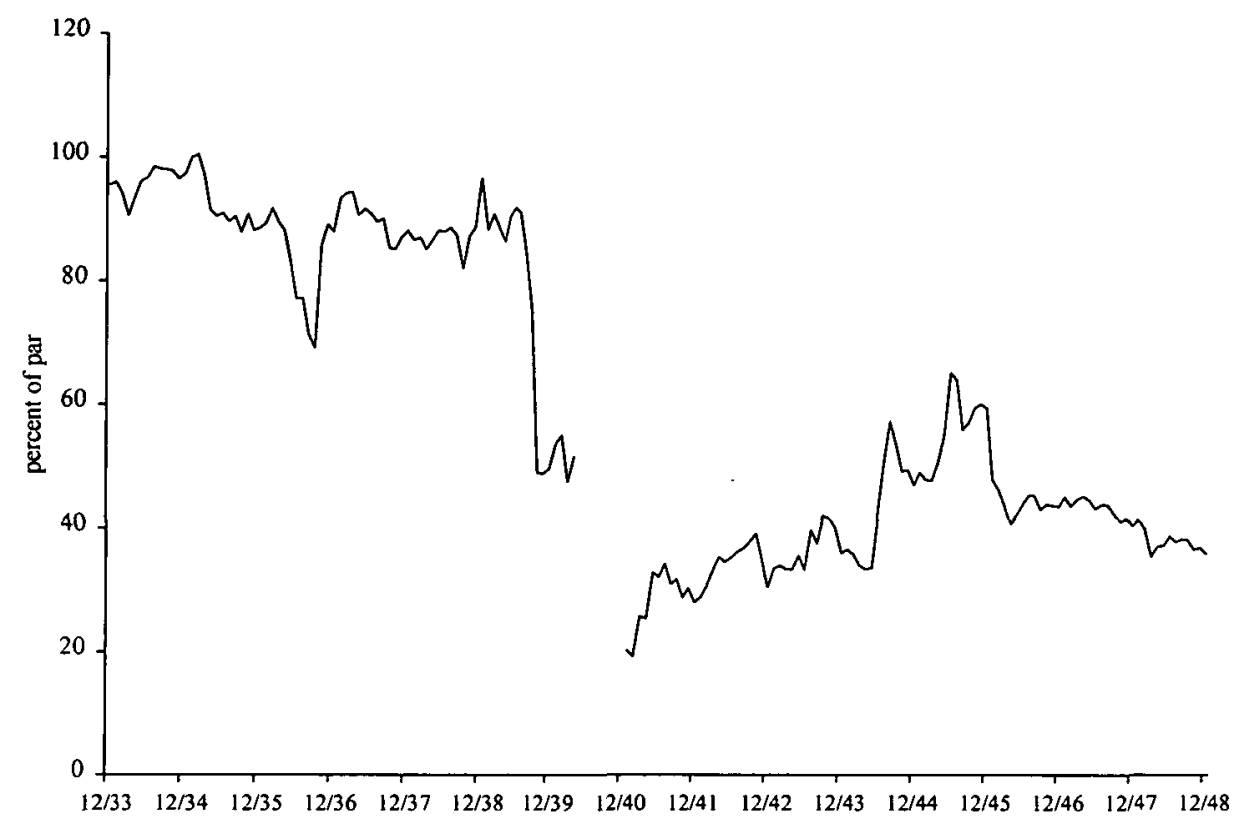

FIGURE 4

INDEX OF 12 FRENCH GOVERNMENT BOND ISSUES TRADED IN SWITZERLAND, 1933-1948

Source: Swiss National Bank, Monatsberichte, 1933-1948.

Our econometric procedure identifies five statistically significant breakpoints in the French series (Table 4). French government-bond values suffered a blow when the Germans occupied the demilitarized Rhineland in May 1936. Investors may at this point have lost some confidence in France's willingness and ability to resist Nazi aggression. The "official" outbreak of war reduced prices still further, as did the defeat of May/June 1940. The Allied invasion of Normandy in June 1944 was greeted as a sign of military and political recovery, and raised French government bond values.

TABLE 4

STRUCTURAL BREAK POINTS AND CORRESPONDNG HISTORICAL EVENTS: FRANCE

\begin{tabular}{lcl}
$\begin{array}{l}\text { Date } \\
\text { (yyyy.mm) }\end{array}$ & $\begin{array}{c}\text { Change in French Bond Index* } \\
\text { (percentages) }\end{array}$ & \multicolumn{1}{c}{ Major Events } \\
\hline 1936.05 & $-4^{* *}$ & German Occupation of the Rheinland \\
1939.09 & $-25^{* * *}$ & German Invasion of Poland \\
1940.05 & {$[-31]^{\mathrm{b}}$} & German Invasion of the Low Countries and France \\
1944.06 & $+16^{* * *}$ & Allied Invasion of Normandy \\
1946.01 & $-14^{* * *}$ & None Identified \\
\hline
\end{tabular}

- Percentage change in the conditional mean (that is, the parameter $\gamma_{s}$ from equation A2).

${ }^{b}$ Difference in the bond values between the day when trading was stopped and when it was resumed. For methodological reasons it is not possible to identify such "breaks" by the econometric techniques used. ** = Significant at the 5 percent level. *** = Significant at the 1 percent level.

Sources: See the text. 


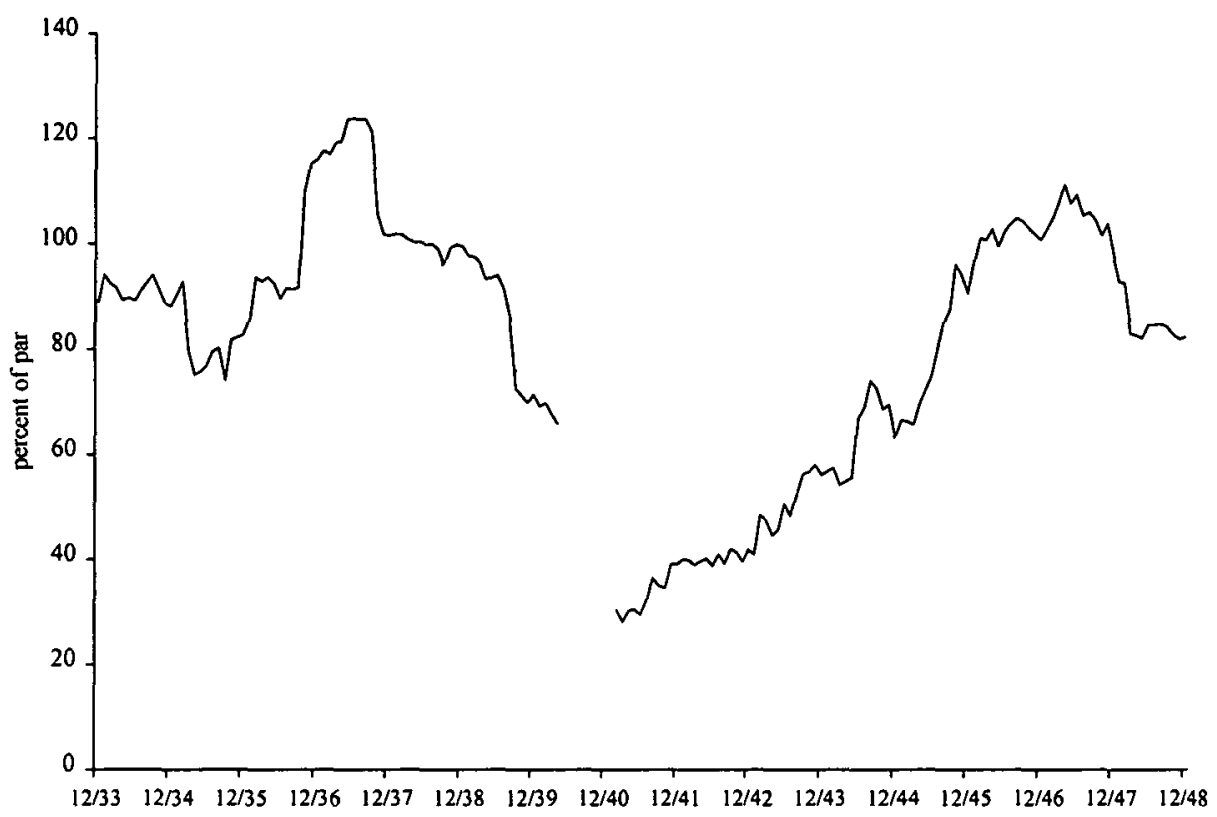

FIGURE 5

INDEX OF 11 BELGLAN GOVERNMENT BOND ISSUES TRADED IN SWITZERLAND, 1933-1948

Source: Swiss National Bank, Monatsberichte, 1933-1948.

Belgium, 1933-1948

The value of Belgian government bonds traded in Switzerland exhibited marked variations (Figure 5). A strong increase from 1934 to 1937 was followed by an even stronger fall, to about 30 percent of par in 1940. Bond values then recovered over the remainder of the war, right up to 1947.

TABLE 5

STRUCTURAL BREAK POINTS AND CORRESPONDING HISTORICAL EVENTS: BELGIUM

\begin{tabular}{lcl}
\hline $\begin{array}{l}\text { Date } \\
\text { (yyyy.mm) }\end{array}$ & $\begin{array}{c}\text { Change in Belgian Bond Index } \\
\text { (percentages) }\end{array}$ & \multicolumn{1}{c}{ Major Events } \\
\hline 1937.09 & $-3^{* *}$ & None Identified \\
1939.08 & $-10^{* * *}$ & German Invasion of Poland \\
1940.05 & {$[-35]^{b}$} & German Invasion of Low Countries and France \\
1943.02 & $+10^{* *}$ & German Capitulation at Stalingrad \\
1944.06 & $+6^{* *}$ & Allied Invasion of Normandy \\
1945.04 & $+7^{* *}$ & German Capitulation(s) \\
\hline
\end{tabular}

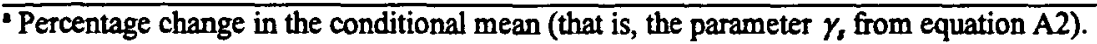

${ }^{b}$ Difference in the bond values between the day when trading was stopped and when it was resumed. For methodological reasons it is not possible to identify such "breaks" by the econometric techniques used. ** = Significant at the 5 percent level. *** = Significant at the 1 percent level.

Sources: See the text. 
Our econometric analysis identifies six break-points in this price series (Table 5). The "official" start of the war, and to a much greater extent the German invasion of May 1940, sent prices plummeting. Allied victories at Stalingrad (February 1943), on the beaches of Normandy (June 1944), and at the very end of the war (April 1945) predictably pushed up the values of Belgian government bonds.

Switzerland, 1928-1948

The overall value of Swiss government bonds shows a long-term rise of about 30 percent over the twenty years from 1928 to 1948 (Figure 6). Values tended to fall in the 1930s. The strong increase in value in 1936 can be attributed to a devaluation of the Swiss currency in September. However, this economic event does not correspond to a statistically significant break in the data, most likely because it also affected the values of all other bonds traded in Switzerland. Prices experienced a marked drop in the three years before the "official" outbreak of the war, until the Blitzkrieg of May 1940. After trading was resumed later that year, Swiss government bonds increased in value until they regained the prewar level of 1936/37.

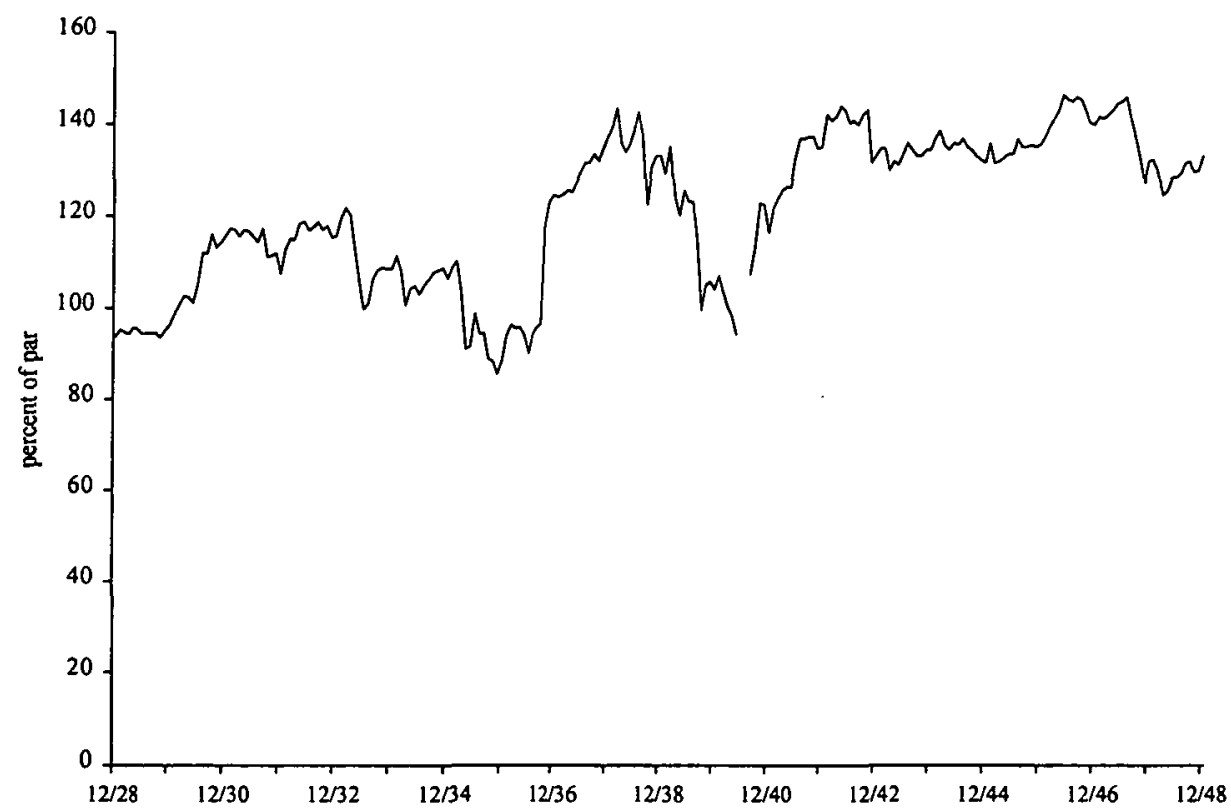


TABLE 6

STRUCTURAL BREAK POINTS AND CORRESPONDNG HISTORICAL EVENTS: SWITZERLAND

\begin{tabular}{lcl}
\hline $\begin{array}{l}\text { Date } \\
\text { (yyyy.mm) }\end{array}$ & $\begin{array}{c}\text { Change in Swiss Bond Index } \\
\text { (percentages) }\end{array}$ & Major Events \\
\hline 1933.04 & $-4^{* * *}$ & Establishment of the Nazi Dictatorship (24 March) \\
1935.03 & $-6^{* * *}$ & $\begin{array}{l}\text { General Draft in Germany } \\
1936.09\end{array}$ \\
1939.10 & $+7^{* * *}$ & Olympic Games in Berlin \\
1940.06 & $+3^{* *}$ & German Invasion of Poland \\
1941.06 & $+4^{* * *}$ & German Invasion of the Low Countries and France \\
\hline
\end{tabular}

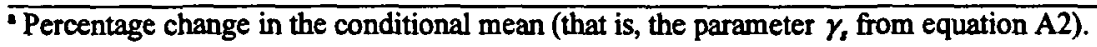

** = Significant at the 5 percent level.

**** = Significant at the 1 percent level.

Sources: See the text.

Econometric analysis reveals six statistically significant break-points, summarized in Table 6. The consolidation of Hitler's dictatorship in the spring of 1933, as well as the reintroduction of the general draft in March 1935 , were considered to be negative events from the point of view of investors in Swiss government bonds. The Olympic Games in August 1936 gave the Nazi government a convenient propaganda forum; Swiss bond values jumped in September 1936, which may be interpreted as a sign that Hitler's government was thereby able to gain some goodwill with investors (as well as with many British, French, and Italian politicians). In view of Switzerland's neutrality, the "official" outbreak of war in September 1939 increased Swiss government bond values the following month. It is likely that funds were shifted into Swiss government bonds, which seemed to be safer than those of the four other countries considered here (all of whose values fell). A similar pattern appeared in June 1940, after the German invasion of the Benelux countries and France, and again after the invasion of the Soviet Union in June 1941. In both cases, the attacks were directed at countries other than Switzerland, so that this country's position as a safe haven improved. In particular, Hitler's decision to outflank the Maginot line in the north, instead of south through Switzerland, was a lucky event.

\section{HISTORICAL FACTS AND GOVERNMENT BOND VALUES}

This section analyzes first, whether historical "facts" related to World War II, and generally considered to be important by historians, show up as statistically significant break-points in the government bonds of the five countries considered, and if so when; second, in what direction, and by how much, the bond values changed. And third, as pointed out in the introduction, it is also important to consider what historical "facts" are not reflected as break-points in government bond values. 
The literature we have consulted takes the following seven events to have been turning points in World War II: the German invasion of Poland on 1 September 1939, marking the "official" outbreak of war; the German invasion of Benelux and France in May 1940; the German invasion of the Soviet Union in June 1941; the war entry of the United States following the Japanese attack on Pearl Harbor in December 1941; the German defeat at Stalingrad in February 1943; the Allied invasion of Normandy in June 1944; and the German capitulation of May 1945, marking the "official" end of the war. ${ }^{24}$

One interesting question we are in a position to answer is whether the dates marking the "official" beginning and end of World War II correspond to the evaluations of investors. As virtually all historians agree that the war was initiated by the Nazis, we include the following seven important historical events occurring in Germany in the period before the "official" outbreak: Hitler's appointment as chancellor in January 1933, and the Enabling Act of March 1933 which gave Hitler essentially unlimited power; the Röhm Putsch of June/July 1934, whereby Hitler vitiated the SA and reestablished the Wehrmacht as the sole military force; the reintroduction of the general military draft in March 1935; the invasion of the demilitarized Rhineland in March 1936; the Olympic Games in Berlin in July and August 1936; the Anschluss of Austria in March 1938; and the invasion of Czechoslovakia in March 1939, whereby Hitler broke his formal promise, given at Munich, that the Sudetenland was his last territorial ambition.

In the same vein, the following two historical events are included in order to test whether the "official" end of the war also marked the end according to capital-market data: the Yalta Conference, where the principle of Germany's unconditional surrender, and its division into three sectors of occupation, was decided. This conference took place in February 1945, that is, before capitulation, but it referred to postwar arrangements; and the Potsdam Conference of August 1945, where (among other issues) Austria's rebirth as a nation was decided.

Table 7 lists the 16 historical events just mentioned and indicates the statistically significant changes in the government-bond values of the Axis powers (Germany and Austria), the neutral countries (Switzerland and Belgium), and one Allied nation (France). The table speaks for itself and it suffices therefore to concentrate on the most important aspects. Only one event, the "official" outbreak of the war, produced a statistically significant break-point in all five countries in our sample. It greatly reduced the value of the government bonds of all belligerents: investors thus did not "pick a winner" but considered the war to be a general threat to their assets. Neutral

\footnotetext{
${ }^{24}$ In view of the capital-market data available, we restrict our attention to the European theater of World War II. A comprehensive overview can be found in Weinberg, World at Arms.
} 


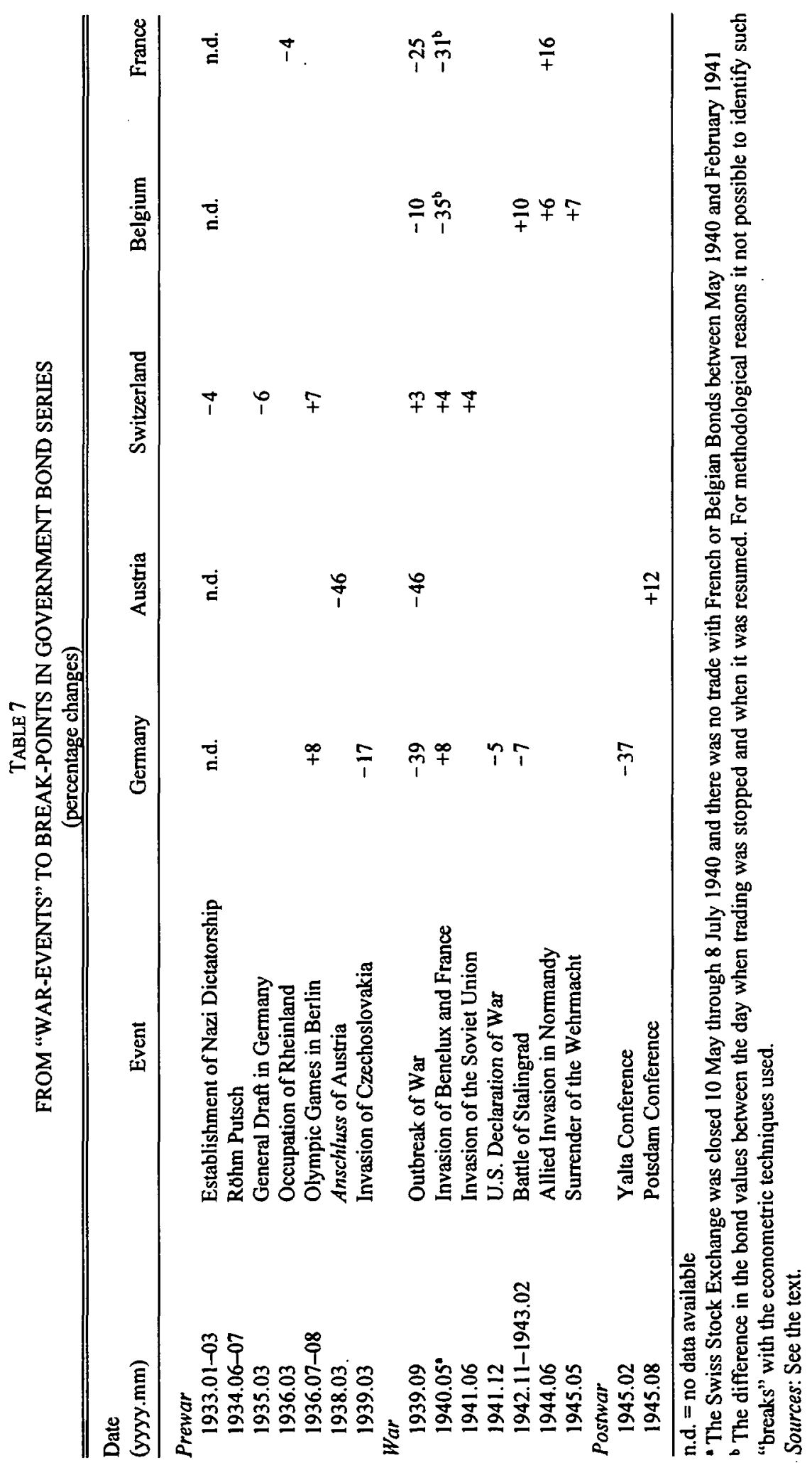


Belgium was also negatively affected, probably because investors thought that it would likely be drawn into a military conflict between Germany and France, a prediction that proved correct. The falling price of bonds issued by belligerent governments stands in contrast to a modest increase in value of Swiss government bonds, because that country was considered a (relatively) safe haven. Econometric analysis thus leads to the same evaluation as does traditional historical research. It is worth noting, however, that major events before that date are also clearly reflected on the bond market, most importantly the German invasions of the Rhineland and of Czechoslovakia.

Another set of historical "facts" clearly reflected in the bond market are major changes in national sovereignty. When a government disappeared (Austria in 1938, Czechoslovakia in 1939, and Germany in 1945) or was occupied (Belgium and France in 1940), the price of its debt experienced a very marked drop. Conversely, when a government reemerged (Austria in 1945 ), its bond values rose sharply.

Several wartime events considered important by historians are reflected as significant break-points in bond values. In addition to the major German invasions (Rhineland, Austria, Czechoslovakia, Benelux, France, and the Soviet Union), this also holds true for two engagements generally considered decisive in Germany's ultimate defeat: Stalingrad and Normandy. On the other hand, viewed from the bond market, the end of World War II is defined less by the German surrender (which affected Belgian bond values only) than by the Yalta and Potsdam Conferences, where the fate of the defeated countries was decided.

\section{THE POSTWAR FATE OF BOND PRICES}

The reader may wonder what happened to bond prices after the war. Was the market correct in its assessment-suggested by the very low value of bond prices at the end of the war-that most European countries would not service their debts for a considerable time to come?

Table 8 depicts the value of bonds issued by four of the five European governments under study. (Switzerland is excluded because it never stopped interest payments, and values for the Swiss government bonds remained above par almost throughout the war.) The most obvious feature is that the four countries' bond prices developed very differently. While Belgium resumed interest payments almost immediately after the war (such that its bonds reached par as early as 1946), Germany, for example, did not resume general debt service until 1954. Common to all countries under consideration is the fact that their postwar governments acknowledged all sovereign debt and did eventually resume service. None of the countries, however, offered investors compensation for the interest payments foregone during the war. 
TABLE 8

VALUES OF FOREIGN-GOVERNMENT BONDS TRADED IN SWITZERLAND AFTER WORLD WAR II

(percentage of par)

\begin{tabular}{lcccr}
\hline $\begin{array}{l}\text { Date } \\
\text { (yyyy.mm) }\end{array}$ & Germany & Austria & France & Belgium \\
\hline 1945.12 & 21.18 & 39.99 & 59.67 & 90.45 \\
1947.12 & 16.72 & 30.40 & 40.41 & 97.97 \\
1949.12 & 39.50 & 49.03 & 44.65 & 101.52 \\
1951.12 & 48.15 & 64.09 & 73.72 & 99.37 \\
1953.12 & 89.89 & 102.95 & 78.70 & 104.77 \\
1955.12 & 99.84 & 108.54 & 83.89 & 103.85 \\
\hline
\end{tabular}

Source: Swiss National Bank, Monatsberichte, 1948-1956.

There is a large literature on when and why governments repudiate debts. ${ }^{25}$ There are several models of the conditions under which regimes decide to repudiate debts incurred by either earlier regimes or in the service of aims for which they do not think their people should pay (such as fighting against the Nazis). In the light of these models, it seems quite clear that those countries which relied most heavily on new foreign credits tried to resume payments as soon as possible. In our sample, this was the case especially for Belgium and (to a lesser degree) Austria. As a consequence, Belgian government bonds had already reached par in 1946, Austrian bonds in 1952.

As is well known, Germany lost a great deal of its productive capacity during the war (and, in the Soviet zone, thereafter as well). While a currency reform was undertaken in the Western zone in 1948 to cope with the ensuing hyperinflation, rationing could not be totally lifted until 1950 . Until the currency reform in 1948, it was unclear whether the new German government would pay its predecessor's foreign debt. As a consequence, the price of its bonds fell to as low as 15 percent of par. It was only in August 1953 that West Germany began to service English and Swiss foreign debts; full service on all foreign debts was resumed in the third quarter of $1954 .^{26}$

In France, government debt had tripled between 1939 and 1945 while industrial production fell by 80 percent. In order to cope with the resulting high inflation, the post-Vichy government conducted a currency reform in 1946 , accompanied by the introduction of heavy taxes on capital. The result was a deep recession in 1947/48, which the government tried to combat with heavy interventions financed through new credits from the United States and from the European Recovery Program (ERP). The French government only resumed servicing its foreign debt at the end of 1949. As can be seen from

\footnotetext{
${ }^{25}$ For a good survey on how debts were repudiated in the 1930s, see Eichengreen and Portes, "Debt."

${ }^{26}$ See for example Die Wirtschafislage, 1953-1954.
} 
Table 8, bond traders nevertheless remained quite pessimistic about France's long-term capacity to service its foreign debt right up to the end of 1955.

\section{CONCLUDING REMARKS}

The approach suggested here focuses on the capital market and seeks to identify statistically significant break-points reflecting historical events. This allows a quantitative assessment of beliefs at a particular point of time, uncontaminated by later events that might otherwise influence the evaluation. This approach has been applied to an important recent period in European history, from Hitler's rise to the Marshall Plan. It has been made possible by the fact that the Swiss market for the bonds of various governments involved in the war essentially functioned without regulatory interventions during the whole period. Analyzing break-points in the values of government bonds obviously focuses on a very specific area, and can therefore only capture one aspect of the wartime experience. The analysis suffers also from a lack of information on the buyers and sellers of the government bonds traded in Switzerland during the war. But it does not follow that capital-market data provide a systematically distorted picture. Persons and institutions active on capital markets have a direct pecuniary incentive to evaluate the prospects of the bonds of the various governments as "objectively" as possible. They cannot afford-at least not in the long run-to follow their own political preferences with respect to the countries involved in the war, because such action would result in systematic losses.

We have analyzed the value of government bonds of five countries more or less affected by the war over the period 1933 to 1948 . We find that the statistically significant break-points identified by the econometric technique described in the Appendix reflect historical events also considered important by historical research based on more conventional techniques. We find, in particular, that the German invasion of Poland prompted a major downward shift in the bond values of all four countries directly involved in the war, while Switzerland benefited modestly. Investors considered it more likely that the Swiss government would be better able to service its debt than would Germany, Austria, France, or Belgium.

Significant changes in the value of government bonds also occurred when nations were invaded, as happened to Austria in March 1938, Czechoslovakia in March 1939, Belgium and France in May 1940, the Soviet Union in June 1941, and France again in 1944. The final capitulation of the Wehrmacht in May 1945 did not affect government bond values (except for Belgium's), which suggests that the German defeat was predicted much earlier by the traders, and was therefore already reflected in bond prices. More relevant was the decision of the Allied powers at Yalta to accept only a total 
capitulation on all fronts. The Potsdam decision to restore Austria's statehood was predictably associated with a significant rise in the price of that government's bonds.

Analyzing breaks in capital-market data are of most use when considered along with events identified and interpreted by more conventional historical research. This article has followed two different tacks: from the break-points determined by the econometric methods to historical events, and from the major historical events to break-points. In both cases the correspondence is incomplete-some break-points and their signs remain difficult to link with historical "facts." There are several reasons why such deviations may have occurred: we may be ignorant of important "facts" of which professional historians are well aware; historians are themselves unaware of the "facts," or have chosen to ignore them; or no such "facts" exist, at least not in the grand arena of high politics: specifically, break-points may have been driven by purely financial news.

Conversely, there are a number of reasons why historical "facts" may not show up as break-points: First, bond-market data may be of poor quality, for instance if there are too few transactions. Second, governments may have intervened in the bond market as buyers or sellers, or by imposing controls of one sort or another. An important case in point occurs when governments want to prevent the reflection of a political (or economic) event on the financial market. What might particularly affect our analysis are changes in capital-market restrictions. Third, the econometric technique applied may be unable to identify break-points relating to historical events, even though they are in the data. Fourth, a "fact" may be important from the historian's point of view (it relates to the fate of a nation, country, or population), but does not affect government debt service. And fifth, the "fact" may not exist, or is not as important as historians believe. Here the quality of historical research is in question. However, it would be misleading to assume that all historians identify the same "facts" as important. So the issue is which historical school or which individual historians have identified which historical "fact," as well as the importance attributed to it. ${ }^{27}$

One of the next steps in research should be to identify which of these reasons are relevant, and under which circumstances. The purpose of this article has been to suggest that such an interaction, between quantitative and qualitative historical research, and between capital market data and data derived from other sources, is capable of providing new insight into historical processes.

${ }^{27}$ See for example Kozicki, Developments. 


\section{Appendix: Econometric Estimation Procedure}

Our approach is designed to find structural breaks in the series of bond prices. In what follows, we will only discuss technical details of the second method applied, that is, the conditional tests. For the unconditional estimation, we adapted the procedure by simply not correcting for the overall index. All other steps involved remain the same.

To address this task, we follow a sequential test procedure based on Banerjee, Lumsdaine, Stock, Sobel, Willard, Guinnane, and Rosen in their analyses of the Greenback market. ${ }^{28}$ In order to find all possible structural breaks, a four-step procedure is applied. Using data from a 36-month window starting in December 1933 (December 1928 for Switzerland), we first estimate the regression

$$
\ln p_{t}=\beta_{0}+\beta_{1} \ln p_{t-1}+\beta_{2} \ln \bar{p}_{t-1}+\varepsilon,
$$

where $p_{t}$ stands for the index-value of all government bonds of the country considered on date $t, \bar{p}$, is the index of all government bonds traded in Zurich (which we use as a measurement of the market performance as a whole), the $\beta$ 's are the parameters to be estimated, and $\epsilon$ is a white-noise error term. A Wald test associated with the hypothesis that there is a structural break in the middle of the window is then calculated. The idea behind step one is to estimate a random walk and then check for changes in the constant, which is the procedure followed in recent stock-market studies. It implies that bond prices follow an exponential Brownian motion. ${ }^{29}$ (We also ran regression with autoregressive processes of up to the sixth order, but did not find different results.) The inclusion of a measure of market performance as a right-hand variable allows us to estimate the random walk ceteris paribus: for example, we allow for factors that might influence the value of all bonds traded (such as fluctuating real interest rates and inflation).

In a second step, we estimate the regression again, this time using a 36-month window beginning one month later. This step is repeated until the entire period has been covered. An example is given in Appendix Figure 1, which depicts the $F$-statistics from all the Wald tests for Germany. By searching for peaks in the series of $F$-statistics, the first two steps identify seven dates for Germany, five for Austria, seven for Switzerland, six for Belgium and five for France, where the null hypothesis of no structural breaks is most strongly questioned. The third step consists of choosing the windows around these dates. As an example, a time window around February 1945 is marked in Appendix Figure 1.

In the fourth step, we test for statistically significant structural breaks within each of the windows isolated in step three. We do this by estimating a series of the following equations, which in comparison with equation $A 1$ have been extended by a dummy variable: ${ }^{30}$

$$
\ln p_{t}=\beta_{0}+\beta_{1} \ln p_{t-1}+\beta_{2} \ln \bar{p}_{t-1}+\gamma_{s} D_{s t}+\varepsilon_{1} \text { with s }=6, \ldots, 42
$$

where $D_{s t}$ equals one if date $t$ is on or after date $s$, and zero otherwise. The parameter $\gamma_{s}$ measures a change in the conditional mean (that is, a shift in the mean price index ceteris paribus) that occurs on date $s$. Since all the prices are in logs, $\gamma_{s}$ can be interpreted as the percentage change in the conditional mean. We estimate equation A2 repeatedly, each time moving $s$ by one month. For each resulting equation, we test whether $\gamma_{s}$ is different from zero using a conventional $F$-test. The date associated with the highest $F$-statistic is then

${ }^{22}$ Banerjee, Lumsdaine, and Stock, "Recursive and Sequential Tests"; Sobel, "Exchange Rate"; and Willard, Guinnane, and Rosen, "Turning Points."

${ }^{29}$ An overview can be found in Duffie, Dynamic Asset Pricing.

${ }^{30}$ As suggested by Perron, "Great Crash." 


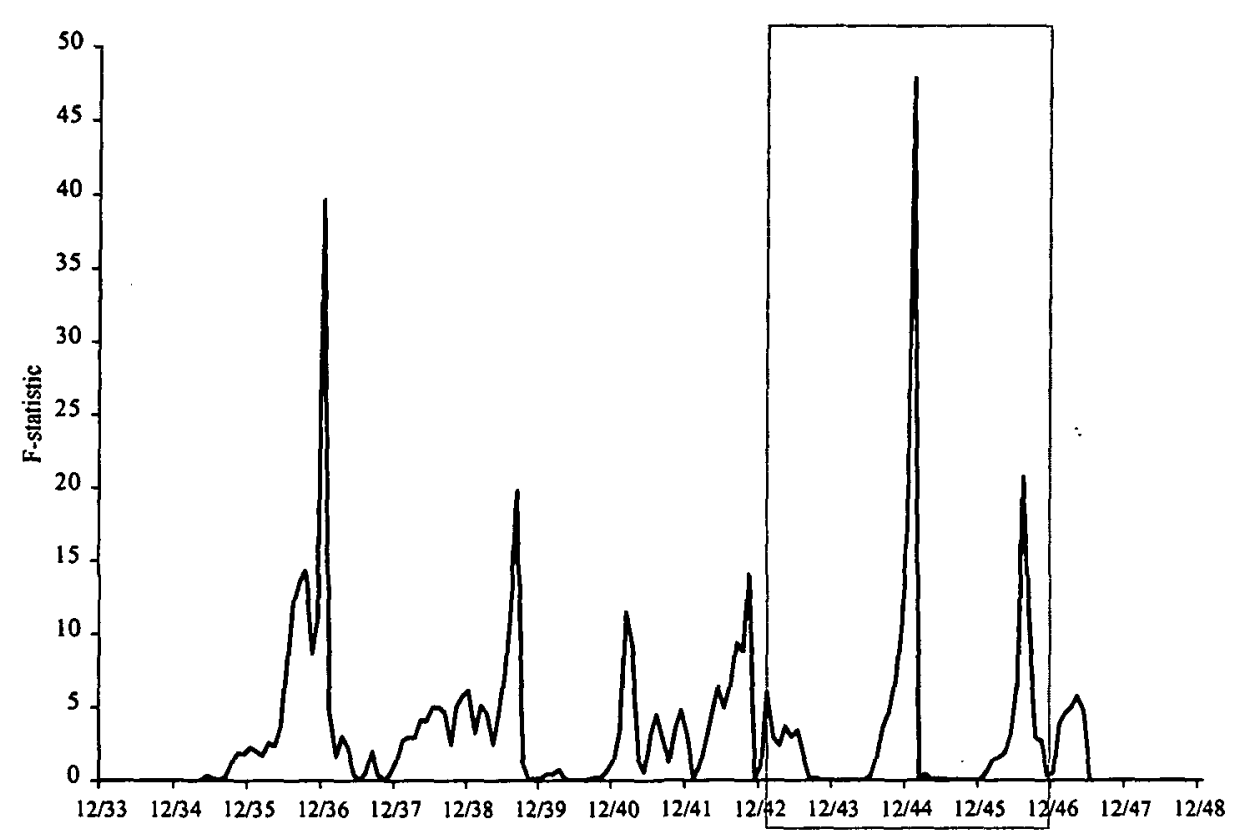

\section{APPENDIX FIGURE 1 \\ F-TESTS FOR STRUCTURAL BREAKS IN THE INDEX OF GOVERNMENT BOND PRICES: GERMANY, 1933-1948}

Source: See the text.

designated as the date where the most important mean shift took place within each window. Since sequential break tests cannot identify breaks around the beginning or end of a sample, we add six observations at the beginning and at the end of the windows examined. So, for the first equation estimated in step four, $s$ is set at date six of the new window (which equals date one in the original window). As an example, the results of step four for the window isolated in Appendix Figure 1 are shown in Appendix Figure 2.

Three further points warrant comment: first, applying only the last step of this procedure to the data would yield inappropriate results, since the last step was developed under the assumption that there is only one break-point in the series. If there is a second shift which reverses the first, the algorithm described in step four might very well miss both of them. To address the problem, we look for mean shifts in short "windows" only. Hence we need steps one to three to determine which periods we should look at.

Second, since the bond price series contain a unit root, test statistics based on regression residuals will have a nonstandard distribution. For step four, we therefore generate Monte Carlo critical values for the Wald test under the null hypothesis of no structural breaks. Critical values for the $F$-tests of no breaks are approximated with 5,000 Monte Carlo simulations of the equation

$$
\ln p_{t}=c+\ln p_{t-1}+\varepsilon_{t}
$$

with $c=0.1$ and $\operatorname{se}\left(e_{t}\right)=0.1$. The resulting 90-, 95-, and 99-percent critical values are 3.14, 4.32 , and 8.00 , respectively. 


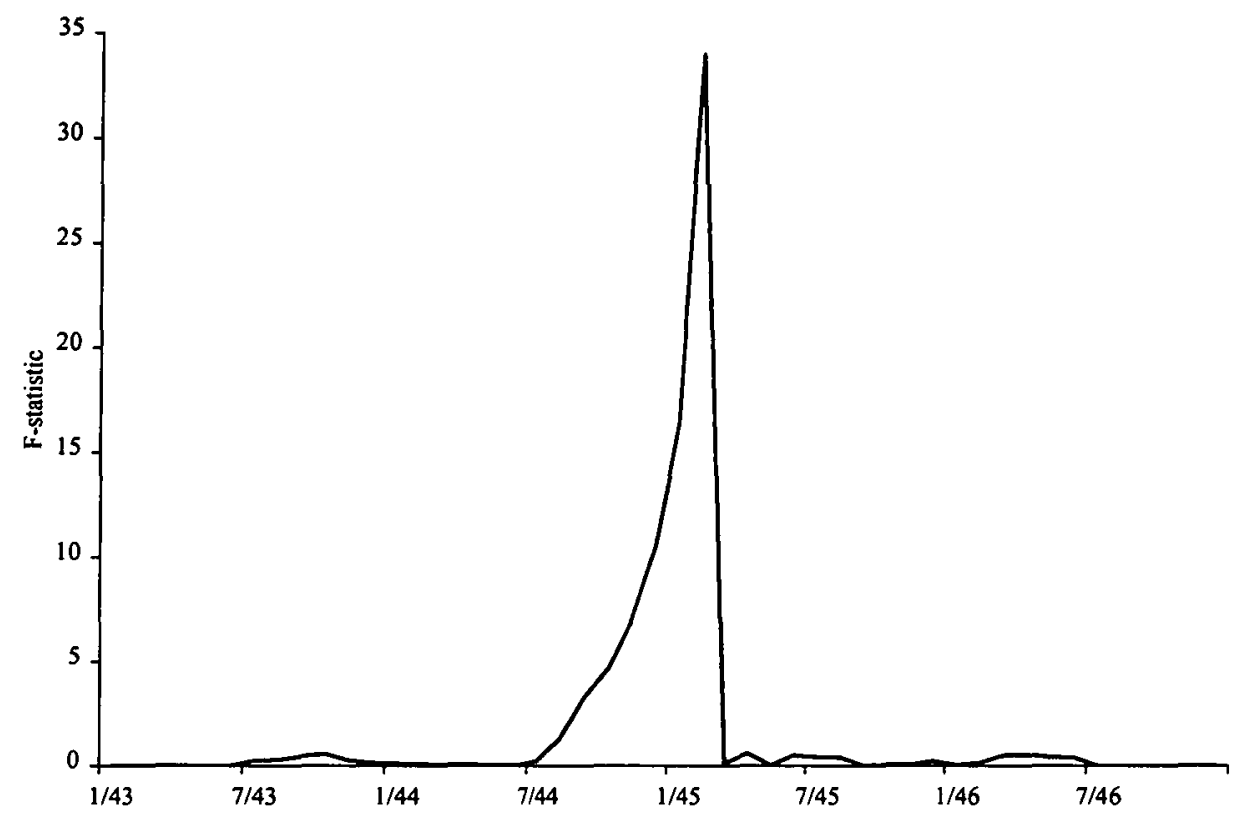

\section{APPENDDX FIGURE 2}

$F$-TEST FOR GERMAN BONDS, TIME WINDOW JANUARY 1943 TO DECEMBER 1946

Source: See the text.

Finally, we also test for variations of the bond index of a specific country relative to the index of all government bonds traded in Zürich. That is, we rewrite equation A1 as

$$
\ln p_{t}-\ln \bar{p}_{t}=\beta_{0}+\beta_{1} \ln p_{t-1}+\beta_{2} \ln \bar{p}_{t-1}+\varepsilon_{t}
$$

Such a specification would seem to be more in line with the excess-return literature frequently used in finance studies. ${ }^{31}$ However, we find the same breakpoints as with the first procedure suggested, and the size of the effect does not change dramatically (none are reversed). Since we believe that the coefficients of the specification presented in equation Al are more easily accessible, only the first specification is used.

The capital market is simultaneously influenced by a great number of factors. The econometric method suggested here allows us only to control some of them. Nevertheless, the results of our analysis are encouraging.

${ }^{31}$ See for example Campbell, Lo, and MacKinlay, Econometrics.

\section{REFERENCES}

Banerjee, Anindya, Robin L. Lumsdaine, and James H. Stock. "Recursive and Sequential Tests of the Unit Root and Trend Break Hypotheses: Theory and International Evidence." Journal of Business and Economic Statistics 10, no. 3 (1992): 271-87.

Boelcke, Will A. Die Kosten von Hitlers Krieg. Kriegsfinanzierung und finanzielles 
Kriegserbe in Deutschland 1933-1948. Paderborn: Schöningh, 1985.

Campbell, John Y., Andrew W. Lo, and Craig A. MacKinlay. The Econometrics of Financial Markets. Princeton, NJ: Princeton University Press, 1997.

Crettol, Vincent, and Patrick Halbeisen. Die währungspolitischen Hintergründe der Goldtransaktionen der Schweizerischen Nationalbank im Zweiten Weltkrieg. Zürich: Schweizerische Nationalbank, 1999.

De Bondt, Werner, and Richard Thaler. "Does the Stock Market Overreact?" Journal of Finance 40, no. 3 (1985): 793-805.

Duffie, Darrell. Dynamic Asset Pricing Theory. Princeton, NJ: Princeton University Press, 1996.

Eichengreen, Barry, and Richard Portes. "Debt and Default in the 1930s: Causes and Consequences." European Economic Review 30, no. 3 (1986): 599-640.

Erbe, René. Die nationalsozialistische Wirtschaftspolitik 1933-1939 im Lichte der modernen Theorie. Zürich: Polygraphischer Verlag, 1958.

Fama, Eugene F. "Efficient Capital Markets: II." Journal of Finance 46, no. 5 (1991): $1575-617$.

Federau, Fritz. Der Zweite Weltkrieg. Seine Finanzierung in Deutschland. Tübingen: Wunderlich, 1962.

Fischer, Wolfram. Die Wirtschaftspolitik des Nationalsozialismus. Lüneburg: Landeszentrale fur Politische Bildung, 1961.

Forsythe, Robert, Forrest Nelson, George R. Neumann, and Jack Wright. "Anatomy of an Experimental Political Stock Market." American Economic Review 82, no. 5 (1992): $1142-61$.

Hardach, Gerd. Der Marshall-Plan: Auslandshilfe und Wiederanfbau in Westdeutschland 1948-1952. München: dtv wissenschaft, 1994.

Henschy, Reg. Freedom at Midnight: Austria 1938-55: A Story of the Traumatic Years of Occupation. Worcester: Billings and Son, 1989.

Jost, Hans-Ulrich. Politik und Wirtschaft im Krieg: die Schweiz, 1938-1948. Zürich: Chronos, 1998.

Köllner, Lutz. Militär und Finanzen. Zur Finanzgeschichte und Finanzsoziologie der Militärausgaben in Deutschland. München: Bernard und Graefe, 1982.

Kozicki, Henry, ed. Developments in Modern Historiography. New York: St. Martin's Press, 1993.

Milward, Alan S. War, Economy and Society. London: Penguin, 1977.

Moos, Herbert von. Das grosse Weltgeschehen. Bern: Hallwag, 1940-1945.

Parrish, Scott D., and Mikhail M. Narinsky. New Evidence on the Soviet Rejection of the Marshall Plan. Washington, DC: Woodrow Wilson International Center for Scholars, 1994.

Perron, Pierre. "The Great Crash, the Oil Price Shock and the Unit Root Hypothesis." Econometrica 57, no. 6 (1989): 1361-401.

Salis, Jean R. de. Eine Chronik des zweiten Weltkriegs. Zürich: Orell Fuessli, 1981.

Schwab, Hubert. "Der Schweizerische Effektenmarkt 1936-1946." Dissertation, University of Zürich, 1948.

Smith, Vernon L. "Markets as Economizers of Information: Experimental Examination of the 'Hayek Hypothesis'." Economic Inquiry 20, no. 2 (1982): 165-79.

Sobel, Russel S. "Exchange Rate Evidence on the Effectiveness of United Nations Policy." Public Choice 95 (1998): 1-25.

Switzerland. National Bank. Monatsberichte der Schweizerischen Nationalbank. Bern: Schweizerischen Nationalbank, January 1929-January 1949.

Urner, Klaus. Die Schweiz muss noch geschluckt werden. Zürich: Verlag Neue Zürcher Zeitung, 1990. 
Weinberg, Gerhard L. A World at Arms: A Global History of World War II. Cambridge, Cambridge University Press, 1994.

Willard, Kristen L., Timothy W. Guinnane, and Harvey S. Rosen. "Turning Points in the Civil War: Views from the Greenback Market." American Economic Review 86, no. 4 (1996): 1001-18.

Wirtschaftslage, Die. Beilage zum Monatsbericht der Schweizerischen Nationalbank. Zürich: Schweizerische Nationalbank, 1953, 1954. 